Www.jmscr.igmpublication.org

Impact Factor (SJIF): 6.379

Index Copernicus Value: 79.54

ISSN (e)-2347-176x ISSN (p) 2455-0450

crossrefDOI: https://dx.doi.org/10.18535/jmscr/v6i12.26

Journal Of Medical Science And Clinical Research

IGM Publication

An official Publication of IGM Publication

\title{
Histopathological and Cytological features of Warthin like variant of Papillary Carcinoma: A Rare case report
}

\author{
Authors \\ Dr Sheela KM ${ }^{1}$, Dr Ashida M Krishnan ${ }^{2}$, Dr Abinaya.L ${ }^{3}$ \\ ${ }^{1,2}$ Associate Professor (CAP), Department of Pathology, Govt. Medical College, Trivandrum \\ ${ }^{3}$ Junior Resident, Department of Pathology, Govt. Medical College, Trivandrum, India
}

\begin{abstract}
Papillary thyroid carcinoma is the most common cancer in thyroid malignancy. Warthin like variant is unusually rare variant of papillary thyroid carcinoma. We report a case of 35 year old female presented with swelling infront of neck for 6 months, with no pressure symptoms, patient is euthyroid. USG revealed suspicious nodules in isthmus FNAC was done and a diagnosis of papillary carcinoma thyroid was given, patient underwent thyroidectomy, HPR revealed Warthin like variant of papillary carcinoma thyroid and itis extending into perithyroidal fatty tissue and skeletal muscle with lymph node metastasis. Here we document cytomorphology and histopathology of this uncommon variant reported in our institution.

Keywords: Warthin like variant of papillary carcinoma, FNAC.
\end{abstract}

\section{Introduction}

Papillary thyroid carcinoma is the most common cancer in thyroid malignancy. Warthin like variant is unusually rare variant of papillary thyroid carcinoma. Apel et al called this subtype as warthin like tumour because it resembles warthin tumour of salivary gland. We report a case of Warthin like variant of papillary carcinoma which is diagnosed in our institution.

\section{Case Report}

35 year old female from Trivandrum is a known case of hypothyroidism for the past 6 years on treatment, noticed swelling infront of neck for 6 months with no pressure symptoms. On local examination a diffuse swelling of thyroid was present on left more than right, which moves with deglutition, lower border palpable.

\section{Investigations}

All the blood routine examinations were within normal limits

USG: Thyroid normal in size, diffusely hypoechoic. Large nodule mea. 17x12x16mm noted arising from upper part of isthumus margins are regular. Few fossa noted within likely calcification. Suspicious nodules in isthumus, suggest FNAC from lesion to exclude papillary carcinoma

FNAC was done. Highly cellular smear shows cells in papillary pattern, concentric whorls, monolayerd sheets and singly. Individual cells have distinct cell borders, moderate amount of pale cytoplasm, pleomorphic round to ovoid vesicular nuclei showing crowding and overlapping Cells showing grooving and intranuclear inclusions noted. Also noted cells in 


\section{JMSCR Vol||06||Issue||12||Page 166-170||December}

clusters and singly with round dense nuclei with moderate eosiophilic cytoplasm Background shows lymphocytes multinucleated giant cells and psamomma body

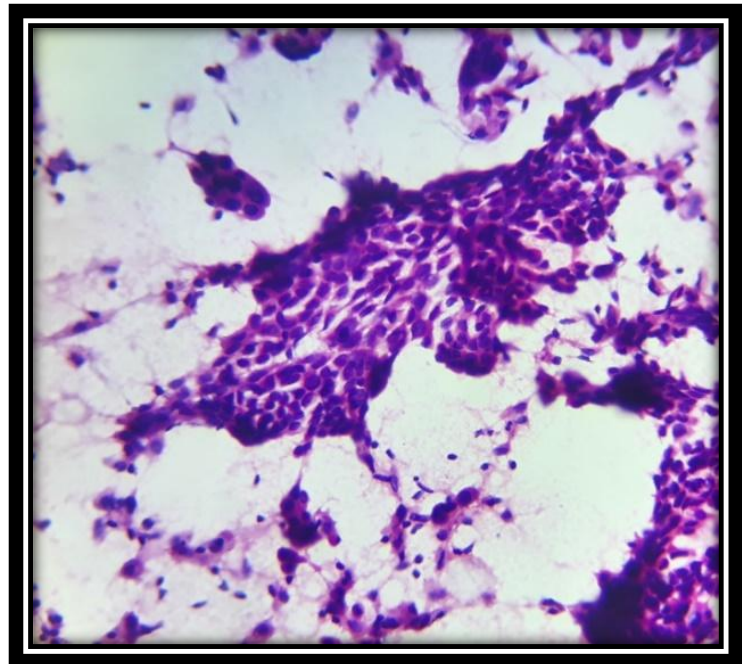

Fig 1: Neoplastic cells arranged in papillary pattern

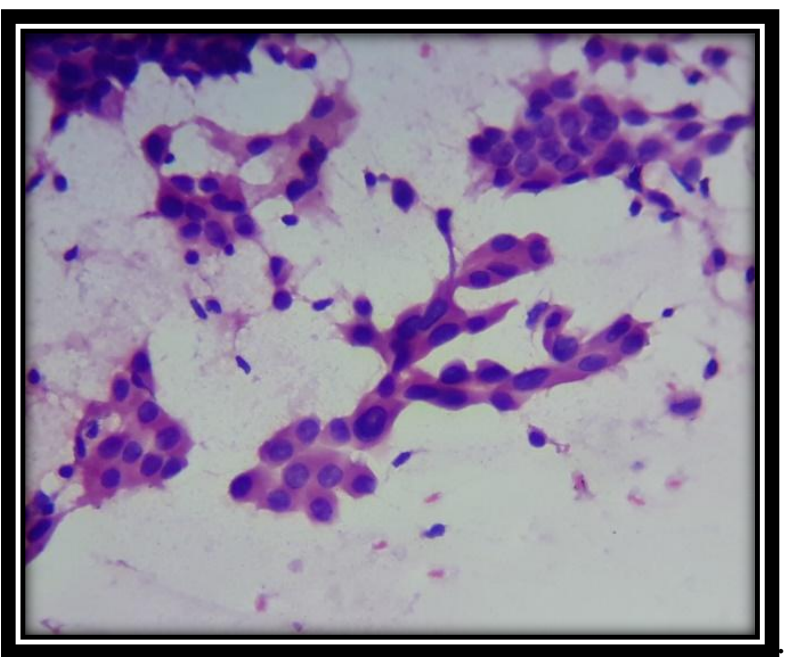

Fig 2: Cells with moderate eosinophlic cytoplasm

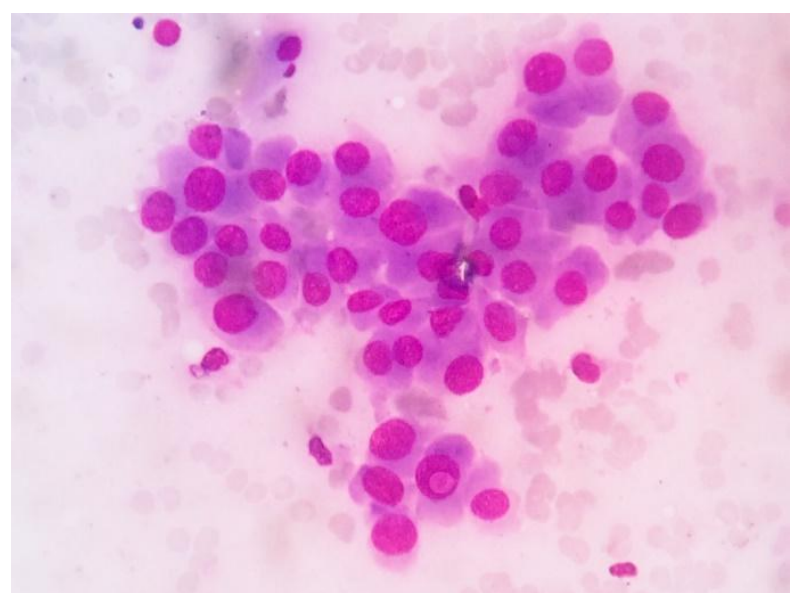

Fig 3: Cells showing intranuclear inclusions

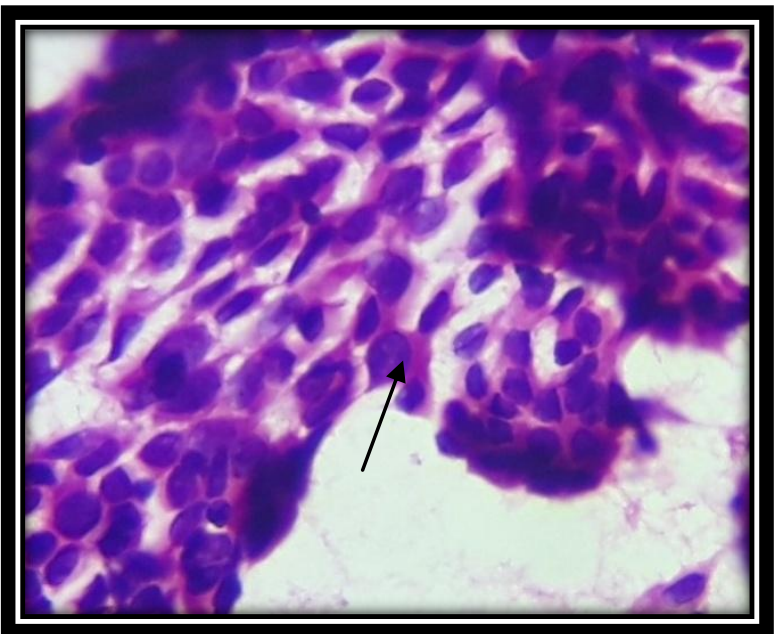

Fig 4: Cells showing grooving.

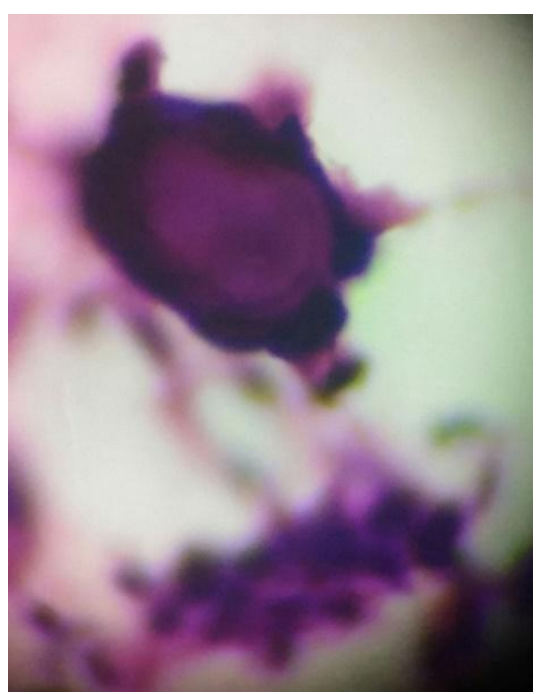

Fig 5: Psamomma body

Patient underwent total thyroidectomy

\section{Macroscopy}

Total thyroidectomy specimen weighs $17 \mathrm{gm}$, Right lobe mea. $4 \times 2 \times 2 \mathrm{~cm}$, Left lobe mea. $3.5 \times 2 \times 2 \mathrm{~cm}$, isthumus mea. $4.5 \times 2 \times \mathrm{cm}$. surface of left lobe shows a rent mea. $5 \times 0.5 \mathrm{~cm}$. Cut section of left lobe shows an ill defined grey white lesion with faint granularity mea. $3 \times 1.2 \times 1 \mathrm{~cm}$, grossly infiltrating the capsule. Cut section isthumus shows diffuse grey white granular area mea. $1.5 \times 2 \times .5 \mathrm{~cm}$.cut section of right lobe showed colloid filled follicles. cut section of fibro fatty tissue identified 2 lymph nodes each mea. $0.5 \mathrm{~cm}$ 


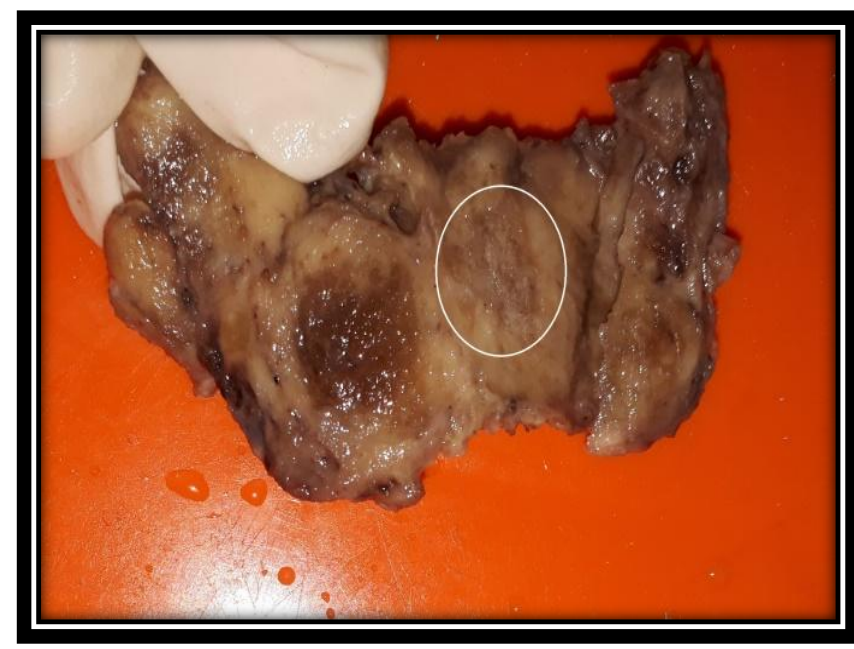

Figure 5: Grey white granular lesion in the isthumus.

\section{Microscopy}

Section from thyroid (Left lobe\& isthumus) shows a neoplasm composed of cells arranged in papillary pattern (fig 6) cells lining the papillae are columnar with oncocytic cytoplasm, enlarged

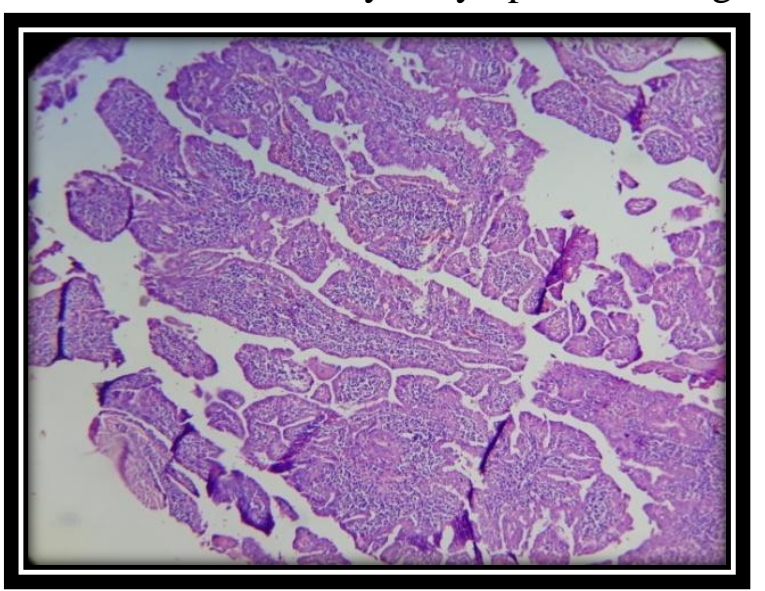

Fig 6: papillary architecture with papillae lined by cells with dense granular eosinophilic cytoplasm

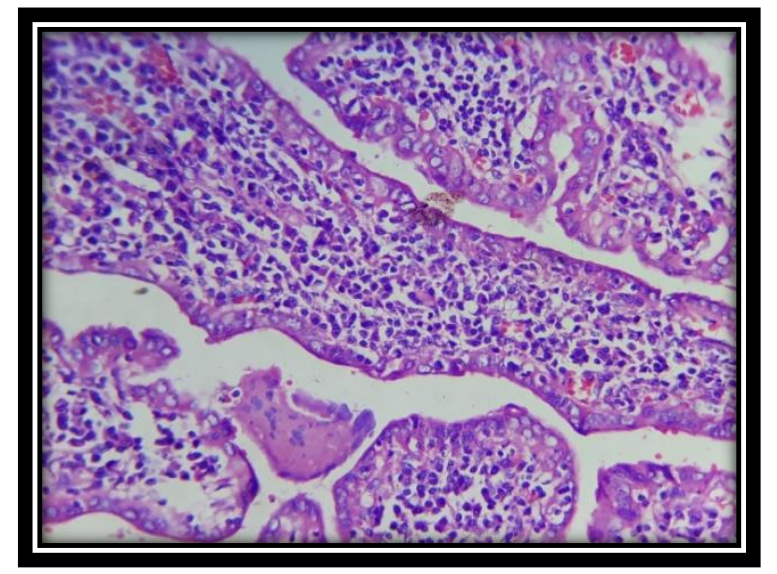

Fig 7 : shows nuclear features of PTC, optically clear nuclei \& overlapping with lymphoplasmacytic infiltrate in papillary stalk nucleus showing nuclear clearing and overlapping. Dense lymphoplasmacytic infiltrate noted in papillary stalks (fig 7). Psammoma body formation seen. Neoplasm is extending into perithyroidal fatty tissue and skeletal muscle. One out of two lymph node shows metastasis from neoplasm.

\section{Discussion}

Apel et al first described Warthin like variant of papillary thyroid carcinoma in 1995 in which 13 cases shows histological features which resembles that of Warthin tumour of salivary gland. ${ }^{1}$

Warthin like variant of papillary carcinoma is a rare variant of papillary carcinoma with approximately 150 cases reported in literature to date $^{2}$

WLPTC is characterized by papillary architecture $\&$ oncocytic tumour cells with nuclear features of papillary carcinoma and brisk lymphoplasmacytic infiltrates in papillary stalks. ${ }^{1,3}$

Papillary carcinoma and its variants can exhibit different degrees of oncocytic metaplasia ${ }^{3}$. Hurthle cell and tall cell variants show prominent oncocytic change.

Warthin-like tumor variant should be differentiated from other variants of papillary carcinoma, such as tall cell variant, Hurthle cell variant, diffuse sclerosing variant, Hurthle cell carcinoma, Hashimoto's disease, and extra parotid Warthin's tumor

Papillary hurthle cell carcinoma comprises 1 to $11 \%$ of all papillary carcinoma and characterized by papillary architecture lined by oncocytic cells with nuclear features of papillarycarcinoma ${ }^{3,1}$. However they usually lack lymphocytic infiltrate and strong association with lymphocytic thyroiditis as seen in warthin like variant.

Tall cell variant of papillary carcinoma is charcterised by papillary growth pattern, oncocytic tumour cell with height twice that of their width $^{3,4,5}$. Tall cell variant can be more aggressive and its frequency associated with extra thyroid extension, vascular invasion, lymph node and distant metastasis. 
Diffuse sclerosing variant has heavy lymphocytic infiltration. However, diffuse sclerosing variant is characterized by the diffuse involvement of one or both thyroid lobes, dense sclerosis, abundant psammoma bodies, extensive solid foci, and squamous metaplasia. ${ }^{6}$

In Hashimoto's disease, oncocytic cells do not emerge as a papillary mass and the nuclear features of papillary carcinoma are not observed. ${ }^{6}$ About $8 \%$ of Warthin's tumors are detected in extra parotid locations such as in the lymphnodes of the cervical region, submandibular gland, minor salivary glands of the oral cavity, pharynx, and larynx. However, true extraparotid Warthin's tumor in sites other than cervical nodes is not widely accepted and does not show the nuclear features of papillary carcinoma. ${ }^{6}$

High detection rate of BRAF was noted in cases of classical PTC ${ }^{7}$ and in literature $75 \%$ of WLPTC express BRAF mutation ${ }^{8}$.

Differentiation of WLPTC from classical PTC is difficult in FNAC and is challenging to differentiate WLPTC from dominant lymphocytic infiltrate. $^{3,9}$

Some reports shows IHC staining can demonstrate that epithelial lining the papillae are immunoreactive for CD15, papillary stalk were positive for CD4 lymphocyte ${ }^{10}$. IHC may be helpful but does not provide definite method for diagnosing of WLPTC.

Prognosis is similar to conventional PTC of similar size and stage.

\section{Conclusion}

WLPTC is a rare variant of papillary thyroid carcinoma and diagnosed mainly by histopathological features which is lymphocytic infiltration of papillary stalks and nuclear characteristics of papillary carcinoma, it is difficult to diagnose by clinical examination, ultrasound and CT. Warthin like variant of PTC is a rare entity with good clinical behavior when compared with other variants of PTC, warranting a proper identification. Our patient after thyroidectomy had undergone radioablation therapy and is doing well now

\section{Conflicts of Interest: Nil}

\section{References}

1. Apel RL, Asa SL, LiVolsi VA. Papillary $\mathrm{Hu}$ " rthle cell carcinoma with lymphocytic stroma: "Warthin's-like tumor" of the thyroid. Am J Surg Pathol. 1995;19:810.

2. Eun Young Kim, Kwan Ho Lee,Young Lai Park, chan Heun Park, Dong Hyun Kim, Seoun Wan Chae,Ji Sup Yun . Warthin like papillary Thyroid carcinoma accompanying classical papillary carcinoma. Int J clin Exp Pathol 2017;10(6):7223-7231.

3. Zubair W. Baloch, MD, PhD; Virginia A. Li Volsi, MD. Warthin-like Papillary Carcinoma of the Thyroid. Arch Pathol Lab Med-Vol 124, August 2000:1192-1195.

4. Rosai J, Carcangiu ML, DeLellis RA. Tumors of the Thyroid Gland. Washington, DC: Armed Forces Institute of Pathology; 1992. Atlas of Tumor Pathology; 3rd series, fascicle 5 .

5. LiVolsi VA. Surgical Pathology of the Thyroid. Philadelphia, Pa: WB Saunders; 1990.

6. Sun Hee Chang, Chang Sig Choi , Yoon Suk Kim. Warthin-like Tumor Variant of Papillary Thyroid Carcinoma, A Case Report. The Korean Journal of Pathology 2004; 38: 200-3

7. Amico P, Lanzafame S, Li Destri G, Greco P, Caltabiano R, Vecchio GM and Magro G. Warthin tumor-like papillary thyroid carcinoma with a minor dedifferentiated component: report of a case with clinicopathologic considerations. Case Rep Med 2010; 2010: 495281.

8. Panayiotides IG, Foukas PG, Meristoudis C, Zourla AP, Peros G and Karakitsos P. Simultaneous occurrence of Warthin-like papillary carcinoma and lymphoma of the mucosa associated lymphoid tissue in Hashimoto thyroiditis. J Clin Pathol 2010; 63: 662-663 
9. Paliogiannis $\mathrm{P}$, Attene $\mathrm{F}$, Trogu $\mathrm{F}$ and Trignano M. Warthin-like papillary carcinoma of the thyroid gland: case report and review of the literature. Case Rep Oncol Med 2012; 2012: 689291.

10. Ersen A, Durak MG, Canda T, Sevinc AI, Saydam S and Kocdor MA. Warthin-like papillary carcinoma of the thyroid: a case series and review of the literature. Turk Patoloji Derg 2013; 29: 150-155. 